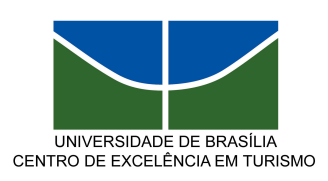

UNIVERSIDADE DE BRASÍLIA

Centro de Excelência em Turismo

Pós-graduação Lato Sensu

Curso de Especialização em Turismo e Desenvolvimento Sustentável

\title{
A EDUCAÇÃO PATRIMONIAL \\ (CULTURAL) E O DESENVOLVIMENTO SUSTENTÁVEL DO TURISMO.
}

\author{
Gabriela Kolberg Figueira
}

Dra. Dóris Sayago 


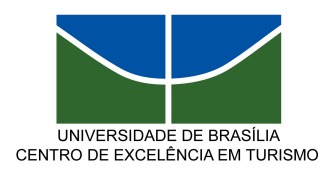

UNIVERSIDADE DE BRASÍLIA

Centro de Excelência em Turismo

Pós-graduação Lato Sensu

Curso de Especialização em Turismo e Desenvolvimento Sustentável

\section{A EDUCAÇÃO PATRIMONIAL \\ (CULTURAL) E O DESENVOLVIMENTO SUSTENTÁVEL DO TURISMO.}

Gabriela Kolberg Figueira

Dra. Dóris Sayago

Monografia apresentada ao Centro de Excelência em Turismo - CET, da Universidade de Brasília - UnB, como requisito parcial à obtenção do grau de Especialista em Turismo e Desenvolvimento Sustentável. 
UNIVERSIDADE DE BRASÍLIA

Centro de Excelência em Turismo

Pós-graduação Lato Sensu

Curso de Especialização em Turismo e Desenvolvimento Sustentável

\section{Gabriela Kolberg Figueira}

\section{Aprovado por:}

Dra. Dóris Sayago (orientadora)

Dra. Ellen Woortmann

Dr. Umberto Euzébio

Brasília, 25 de junho de 2007. 
Este trabalho é dedicado especialmente ao meu pai (em memória), e toda a minha família que sempre está presente em todos os momentos. 


\section{AGRADECIMENTOS}

Agradeço a minha família por tudo, a Dinda pelos puxões de orelha, ao Fernando José pelas palavras de incentivo, ao Helmo por ter apontado as minhas falhas na redação do trabalho, a minha mãe por me proporcionar a oportunidade de fazer este curso, a Luiza pelo apoio nas horas mais dificeis, ao Luciano que mesmo longe sempre se fez muito presente, ao meu pai que está sempre olhando por mim. A minha orientadora Dóris Sayago que mesmo com tantos transtornos não desistiu de me ajudar. Aos amigos que fiz ao decorrer desse curso. A minha companheira de muitas risadas Carolina Lorentz, a organizadora dos encontros da turma Marcionila Sames e seu marido Bernardo, a minha companheira de muitos momentos Fabianne Ykemoto, ao carinho do meu amigo Leonardo Cintra, a sabedoria inquestionável de Alda Ilza, a sensibilidade e a ternura de Rammana Oliveira, ao jeito moleque de Luciano Pangella, as brincadeiras de Carlos Alberto, a alegria de Claudia Moreira, a diverção de Francisco Flávio, os "causos indígenas" de Victor Mauro, as polêmicas de Róbison Castro, as explicações de Patrícia Castro, as conversar sobre patrimônio histórico com Kiara Mesquita, as experiências de Cleuber Vieira, a ingenuidade de Danilo Gustavo, a garra de Elisa Ferreira, a alegria de Fábio Cavalcante, a sinceridade maravilhosa de Guilherme Coutinho, a simpatia acanhada de Josana Lima, o jeito Natércia Silva de ser, enfim todos, amigos que eu vou guardar em meu coração. Aos meus amigos de longe, Alessandro Marinho, Renata Semblano, Raíssa Santiago, Samara Farripas, Carolina Lopes e o meu amigo Rafael Contreira que muitas vezes me fez enchergar o que eu realmente sou. Aos meus amigos de perto Gabriela Lopes, Rossane Luvielmo, Nayara, enfim, todos que sempre estiveram perto, e que fazem parte da minha vida. Agradeço por vocês existirem. 


\section{RESUMO}

O turismo é um fenômeno de interação e interdisciplinaridade que utiliza o patrimônio cultural e natural como atrativo de fundamental importância para sua existência. Contudo, para desenvolver o turismo de forma responsável, seguindo os princípios do desenvolvimento sustentável, é necessário que se tenha consciência em relação a importância do patrimônio e a necessidade de sua preservação. Nesse sentido, a educação patrimonial ocupa um papel de importância fundamental no processo de desenvolvimento do turismo sustentável. Através dela, é possível fazer um trabalho de sensibilização e, conseqüentemente, conscientizar a população em relação à preservação do patrimônio natural e cultural, gerando assim a manutenção da identidade cultural de uma sociedade.

Palavras-chave: turismo; educação patrimonial; sustentabilidade. 


\begin{abstract}
The tourism is a phenomenon of interaction and interdisciplinarity that uses the cultural and natural patrimony as an attractive of basic importance for its existence. However, to develop tourism in a responsible form, following the principles of the sustainable development, it is necessary to have conscience of the importance of the patrimony and the necessity of its preservation. In this direction, the patrimonial education occupies a paper of basic importance in the process of development of the sustainable tourism. Through it, it is possible to make a sensitization work and, consequently, to make de population acquire knowledge in relation to the preservation of the natural and cultural patrimony, thus, generating the maintenance of the cultural identity of a society.
\end{abstract}

Key-words : Tourism; Patrimonial Education; Sustentability. 


\section{LISTA DE SIGLAS}

IBAMA: Instituto Brasileiro do Meio Ambiente e dos Recursos Naturais Renováveis. IEPHA/MG: Instituto Estadual do Patrimônio Histórico e Artístico de Minas Gerais. IPHAN: Instituto da Patrimônio Histórico e Artístico Nacional.

MMA: Ministério do Meio Ambiente.

OMT: Organização Mundial do Turismo.

PCN: Parâmetros Curriculares Nacionais.

PNT: Plano Nacional de Turismo.

PPA: Plano Plurrianual.

SNUC: Sistema Nacional de Unidades de Conservação.

UNESCO: Organização das Nações Unidas para a Educação, a Ciência e a Cultura. 


\section{SUMÁRIO}

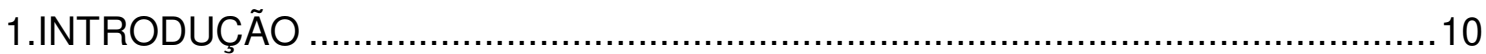

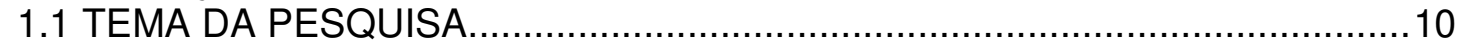

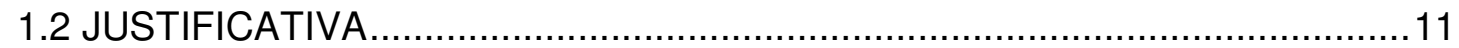

1.3 OBJETIVOS.

1.3.1 Objetivo geral............................................................................

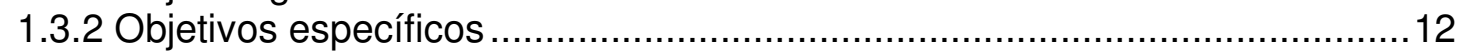

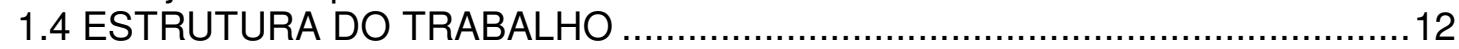

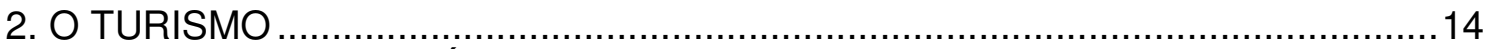

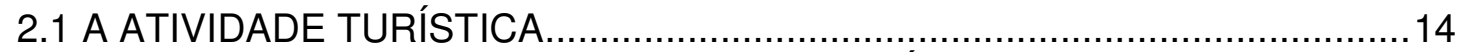

2.2 TURISMO E DESENVOLVIMENTO SUSTENTÁVEL ….............................18

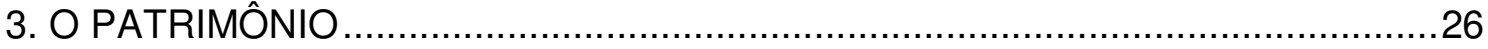

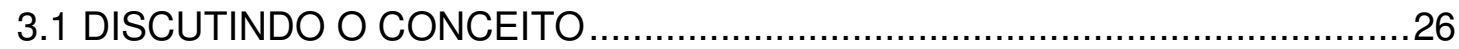

3.2 A EDUCAÇÃO PATRIMONIAL …….................................................

3.3 PATRIMÔNIO CULTURAL E TURISMO ……........................................42

4. TURISMO E PATRIMÔNIO: O OLHAR DO PODER PÚBLICO …......................46

4.1 O Plano Plurianual 2004-2007 - PPA ......................................................46

4.2 O Plano Nacional de Turismo - PNT ..........................................................5

4.3 O Instituto do Patrimônio Histórico e Artístico Nacional - IPHAN......................58

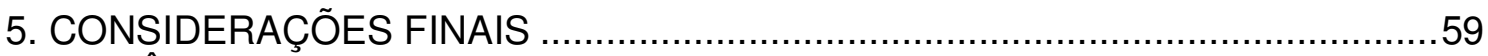

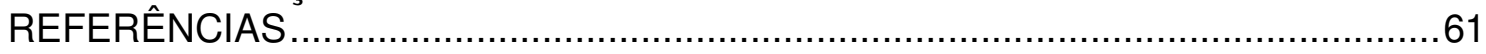




\section{INTRODUÇÃO}

\subsection{TEMA DA PESQUISA}

No contexto do mundo em que vivemos, onde a competitividade é fato em virtude a globalização de mercado, o turismo tem se destacado com importância singular quando refere-se ao patrimônio que cada localidade possui (patrimônio imaterial, material e natural). Estudar formas de usufruir esse patrimônio sem degradá-lo, educando a população em relação à importância desse patrimônio e do desenvolvimento do turismo sustentável corresponde a uma estratégia que vai além das perspectivas do comércio, contemplando também a conservação da cultura das localidades, dos costumes, das manifestações, do patrimônio físico, da natureza, da história, da identidade de um povo.

A importância de desenvolver o turismo de forma sustentável e de ter conhecimento a respeito do patrimônio de cada localidade é notório e fundamental, mais do que isso, é um dever de todos e conseqüentemente um direito também, não apenas do poder público, entretanto, esse deve ser o norteador das ações e dos programas de turismo sustentável e educação patrimonial, apresentando-os com linguagem acessível e capaz de gerar em cada cidadão um certo grau de comprometimento, fazendo com que todos entendam que devemos ter a obrigação, a ação e a vontade de preservar o que é nosso.

Dessa forma, é importante observar que a educação patrimonial não é apenas uma ferramenta de utilidade para o desenvolvimento do turismo sustentável, mas também e principalmente um artifício para a criação da consciência, do ato de cidadania, de conservação da cultura, de preservação de costumes, da história, da memória, da identidade, da vida. 
Sobre a relação entre turismo e patrimônio BARRETO (2001, p. 104), comenta que "a preservação do patrimônio pode ser tanto a causa como a conseqüência do turismo".

PIRES (2003, p. 75), observa que "o turismo é um gerador de emprego e riqueza, mas principalmente, uma grande ferramenta de democratização da cultura".

Portanto, quando falamos de utilização, exploração do patrimônio cultural pela atividade do turismo, não estamos nos remetendo apenas a uma forma exploratória do turismo como atividade comercial, somente e simplesmente geradora de renda e sim a uma consciência conservacionista chamada de turismo sustentável, capaz de usufruir e ao mesmo tempo conservar o patrimônio, colocando-o em evidência para que a cultura não desapareça com o passar dos anos.

\subsection{JUSTIFICATIVA}

Diante da crescente necessidade de conscientizar e sensibilizar a população para a importância de se desenvolver a atividade do turismo em determinada localidade com base nos princípios da sustentabilidade, da necessidade de mostrar que a comunidade dessa localidade e a população em geral, precisam ter plena consciência de seu patrimônio (imaterial, material e natural), haja vista que só se conserva o que se tem apreço, o que se conhece, é que justifica a importância e a relevância da Educação Patrimonial no processo de desenvolvimento do turismo de forma sustentável, da preservação do patrimônio cultural e conseqüentemente justifica a elaboração desse trabalho. 


\subsection{OBJETIVOS}

\subsubsection{Objetivo geral}

Analisar o Plano Plurianual 2004-2007, verificando a forma como o poder público trata as questões relacionadas ao turismo e patrimônio.

\subsubsection{Objetivos específicos}

Mostrar a forma como os autores discutem turismo sustentável, patrimônio cultural e educação patrimonial;

Analisar como o poder público interpreta o turismo, o patrimônio e conseqüentemente a educação patrimonial e a sustentabilidade da atividade turística.

\subsection{ESTRUTURA DO TRABALHO}

O presente trabalho está estruturado de forma bastante sucinta, dividido em cinco partes. A primeira parte consta de uma introdução, onde buscou-se apresentar o tema da pesquisa, sua justificativa e os objetivos para que o trabalho se propõe.

$\mathrm{Na}$ segunda parte é apresentada a fundamentação teórica acerca da atividade turística, do desenvolvimento sustentável do turismo, com conceitos de diversos autores e organizações.

A terceira parte faz uma abordagem em relação ao patrimônio cultural, discutindo conceitos a respeito de patrimônio e educação patrimonial, além de apresentar a relação existente entre o patrimônio e a atividade turística. 
A quarta parte consta da observação e análise do Plano Plurianual Brasileiro, do Plano Nacional de Turismo e das competências do Instituto do Patrimônio Histórico e Artístico Nacional, de forma a observar a maneira como o poder público interpreta o turismo e o patrimônio nacional. 


\section{O TURISMO}

\subsection{A ATIVIDADE TURÍSTICA}

Inúmeras definições acerca do turismo são defendidas por diversos autores, organizações e instituições. Segundo a Organização Mundial do Turismo - OMT, "o turismo compreende as atividades que realizam as pessoas durante suas viagens e estadas em lugares diferentes ao seu entorno habitual, por um período consecutivo inferior a um ano, com finalidade de lazer, negócios ou outros", ressaltando que "o entorno habitual de uma pessoa consiste em certa área que circunda sua residência mais todos aqueles lugares que visita freqüentemente" (OMT: 2001, p. 38).

Nesse sentido, VELOSO (2003, p. 04), considera que o "turismo é uma atividade econômica representada pelo conjunto de transações - compra e venda de serviços turísticos - efetuadas entre os agentes econômicos do turismo. É gerado pelo deslocamento voluntário de pessoas para fora dos limites da área ou região em que têm residência fixa, por qualquer motivo, excetuando-se o de exercer alguma atividade remunerada no local que visita".

Ainda nesse sentido, WAHAB (1977, p. 63), define o turismo como sendo "o complexo de relações e fenômenos relacionados com a permanência de estrangeiros em uma localidade, pressupondo-se que estes não exerçam uma atividade principal, permanente, temporária ou remunerada".

De outro lado, o conceito de OLIVEIRA (2002, p. 36), afirma que "denominase turismo o conjunto de resultados de caráter econômico, financeiro, político, social e cultural produzidos numa localidade, decorrentes do relacionamento entre os visitantes e os locais visitados durante a presença temporária de pessoas que se 
deslocam de seu local habitual de residência para outros, de forma espontânea e sem fins lucrativos".

Dessa forma, FÚSTER, acrescenta que o "turismo é, de um lado, o conjunto de turistas, de outro, os fenômenos e as relações que essa massa produz em conseqüência de suas viagens" ( apud IGNARRA: 2003, p. 13).

Para BARRETO (1991, p. 43), "o turismo é um fenômeno de interação entre o turista e o núcleo receptor e de todas as atividades decorrentes dessa interação".

Já MCINTOSH, observa que "o turismo pode ser definido como a ciência, a arte e a atividade de atrair e transportar visitantes, alojá-los e constantemente satisfazer suas necessidades e desejos" ( apud IGNARRA: 2003, p. 12).

Por outro lado, JAFARI, ressalta que o turismo "é o estudo do homem longe de seu local de residência, da indústria que satisfaz suas necessidades, e os impactos que ambos, ele e a indústria, geram sobre o ambiente físico, econômico e sociocultural da área receptora" ( apud IGNARRA: 2003, p. 12).

Contudo, em sua essência, o turismo nada mais é do que o movimento de pessoas, o atendimento de suas necessidades como também das necessidades das comunidades receptoras e conseqüentemente a interação entre os que viajam, os que ofertam serviços turísticos e as comunidades receptoras.

Entretanto, não podemos deixar de considerar que a atividade do turismo tem se modificado com o passar do tempo, os turistas têm apresentado novas perspectivas, novas necessidades, e nesse contexto é notória a importância dada à sustentabilidade e a consciência conservacionista. Assim, o turismo configura-se 
como uma atividade que tem contemplado com muita propriedade o valor cultural das comunidades e suas manifestações, atribuído o valor e a importância adequada aos bens materiais e imateriais que constituem a base de sustentação da própria atividade, assim como também agrega valor ao patrimônio ambiental de importância fundamental para a qualidade de vida das populações locais.

Diversos autores denominam o turismo como sendo uma indústria, entretanto, o turismo não pode ser considerado apenas como indústria, pois possui relações próprias que integram todos os setores produtivos, formando assim uma espécie de sistema, um sistema que contempla muito mais do que a questão comercial. Um sistema que envolve comunidades, costumes, culturas, histórias, um sistema que utiliza dessas tantas vertentes para sua perpetuação, para sua sustentabilidade como atividade.

Segundo FÚSTER (1947), "turismo é todo o equipamento receptivo de hotéis, agências de viagens, transportes, espetáculos, que o núcleo receptor deve habilitar para atender as correntes turísticas. Turismo é o conjunto das organizações privadas ou públicas que surgem para fomentar a infra-estrutura e a expansão do núcleo turístico".

Contudo, o turismo caracteriza-se como uma atividade multidisciplinar, onde nada lhe é exclusivo, pois recebe a imensa colaboração das mais diversas ciências. Utiliza-se dos conhecimentos da geografia para a delimitação e exploração do território, além de estudar fenômenos naturais, com capacidade de torná-los atrativos turísticos; da biologia para a interpretação dos ambientes, a conservação e defesa da natureza através da educação ambiental; da sociologia e da antropologia para entender suas comunidades e suas respectivas culturas e principalmente 
entender o relacionamento humano; da história, através da educação patrimonial para a criação da consciência cidadã, conservacionista, para a perpetuação da cultura e da natureza; da economia para acompanhar as reações do mercado consumidor; da psicologia para melhor entender as necessidades e anseios tanto dos turistas bem como das comunidades receptoras; do direito, da informática, da estatística, do marketing, da administração, entre tantas outras. O turismo se utiliza também de inúmeras vertentes do mercado para que possa existir, caracterizando assim o mercado turístico, onde estão contempladas as atividades de transportes, acomodação, alimentação, entretenimento, comércio em geral, além de tantos outros atores sociais que contribuem de forma direta ou indireta na construção da atividade turística.

Entretanto, é fundamental ressaltar que o turismo é uma atividade que apresenta uma importância social tão relevante quanto seu desenvolvimento econômico, e deveria ser pensado não apenas como uma fonte de divisas, mas como uma fonte de lazer, entretenimento, e principalmente como ferramenta importante no que diz respeito a manutenção da cultura de um povo, de seu patrimônio, contudo, por não estar sendo pensado de forma racional, responsável e sustentável, o turismo tem muitas vezes degradado a cultura e as tradições das comunidades que dessa atividade tiram seu sustento como também o meio ambiente a que fazem parte, por ser considerada uma atividade meramente econômica, desconsiderando seu papel de caráter fundamental na conservação do patrimônio e sua responsabilidade social.

Contudo, para que se possa explorar a atividade turística sem que ela cause impactos sociais, culturais e econômicos, faz-se necessário a implantação de 
programas de sensibilização, de educação patrimonial, de responsabilidade social, capazes de mobilizar as comunidades e mantê-las envolvidas de forma direta e incondicional no planejamento e na execução da atividade turística, sinalizando assim um comprometimento com a preservação e a conservação do patrimônio, justamente porque só somos capazes de manter, conservar, preservar aquilo que temos como importante, vital, e é dessa forma que devemos enxergar nosso patrimônio.

Para tanto, é imprescindível considerar o turismo, além de uma fonte de emprego, renda e participação social, uma atividade capaz de contribuir de forma responsável para a conservação da diversidade cultural e do patrimônio (seja ele natural ou cultural) de uma sociedade.

\subsection{TURISMO E DESENVOLVIMENTO SUSTENTÁVEL}

$\mathrm{Na}$ atualidade, o conceito de desenvolvimento sustentável vem sendo muito debatido e comentado, contudo, ele foi incorporado como um princípio mundial a partir da conferência das Nações Unidas sobre o Meio Ambiente e Desenvolvimento, a ECO 92, que aconteceu no Rio de Janeiro em 1992, onde ficou estabelecida a relação entre o equilíbrio do ambiente e o desenvolvimento econômico, configurando assim o que chamamos de desenvolvimento sustentável.

O desenvolvimento sustentável a partir de então passou a ser contemplado como prática necessária para quase todas as atividades exercidas pelo homem, e o turismo não foi deixado de lado. 
O turismo sustentável está inserido nas perspectivas do desenvolvimento sustentável, "capaz de atender às necessidades da geração atual sem comprometer os recursos para a satisfação das gerações futuras". (World Commissionn on Environment and Development, 1987).

Dessa forma, o turismo moderno está apoiado nos princípios do desenvolvimento sustentável como ressalta VELOSO (2003, p. 84), sendo estes princípios:

- A sustentabilidade ecológica: proporciona condições que asseguram o desenvolvimento compatível com a manutenção do processo ecológico e ambiental de maneira essencial, com a diversidade biológica e com os recursos naturais;

- A sustentabilidade sociocultural: proporciona e assegura o desenvolvimento com relação ao aumento do controle das pessoas sobre suas próprias vidas, contribuindo para a compatibilidade com a cultura e com os valores das comunidades, além de manter, reforçar a identidade e os costumes da comunidade;

- A sustentabilidade econômica: é a preservação e o controle quanto ao desenvolvimento econômico de maneira eficiente, proporcionando condições legais e regulares para que os recursos sejam geridos de maneira honesta e consciente no sentido de que possam manter para as gerações futuras.

Ângela Maria Rodrigues Ferreira, observa que "o conceito de turismo sustentável está imediatamente ligado à sustentabilidade dos meios natural e cultural, considerados como atrativos básicos do turismo. No entanto, dentro da perspectiva do desenvolvimento sustentável, não podemos dissociá-lo da dimensão econômica e social" (apud MARTINS: 2003, p. 04).

De acordo com a OMT (1995), o turismo sustentável é aquele ecologicamente sustentado em longo prazo, economicamente viável, ético e socialmente eqüitativo 
para as comunidades locais. Exige interação ao meio ambiente natural, cultural e humano, respeitando a fragilidade de cada localidade.

A sustentabilidade é o princípio estruturador do processo de desenvolvimento sustentável do turismo e para que esse desenvolvimento aconteça de forma efetiva é necessário levar alguns fundamentos em consideração, sejam socioeconômicos, socioculturais ou sociopolíticos.

A OMT comenta que "o turismo sustentável não pode funcionar unicamente à base de imposições da administração pública, é preciso também, que o setor turístico privado aceite esse conceito e coopere em sua execução, assim como as comunidades locais e os turistas que devem prestar sua colaboração no processo" (apud DIAS: 2003, p. 68).

Segundo a OMT (2001, p. 246), "o desenvolvimento do turismo sustentável implica a tomada de decisões políticas que podem ser severas e que requerem uma visão a longo prazo, principalmente na hora de efetivar o processo de planejamento".

Contudo, para que se tenha um turismo inserido no contexto do desenvolvimento sustentável é necessário que o maior número de atores sociais tenham participação em todas as fases do processo, esse deve ser contínuo e com ações concatenadas, onde haja comprometimento e conscientização, racionalidade na utilização dos recursos, justiça social, viabilidade econômica, zelo ambiental e compatibilidade cultural, criando condições para que os recursos estejam disponíveis para as gerações atuais e também para as futuras. 
RUSCHMANN comenta que "atualmente, o turismo sustentável procura adequar os interesses de cada um dos parceiros do triângulo (as destinações, os turistas e os prestadores de facilidades para os visitantes), minimizando as tensões e buscando um desenvolvimento a longo prazo, pelo equilíbrio entre o crescimento econômico e as necessidades de conservação do meio ambiente" ( apud ALMEIDA; FROEHLICH: 2000, p. 70).

Segundo a OMT (2003, p. 24), "o desenvolvimento do turismo sustentável atende às necessidades dos turistas de hoje e das regiões receptoras, ao mesmo tempo em que protege e amplia as oportunidades para o futuro. É visto como um condutor ao gerenciamento de todos os recursos, de tal forma que as necessidades econômicas, sociais e estéticas possam ser satisfeitas sem desprezar a manutenção da identidade cultural, dos processos ecológicos essenciais, da diversidade biológica e dos sistemas que garantem a vida".

Portanto, relação estabelecida entre a cultura e meio ambiente no que diz respeito à sustentabilidade do turismo configura-se de forma extremamente direta, uma relação de interdependência.

Ainda de acordo com a OMT (2003, p. 29), "o turismo pode servir de justificativa e auxiliar no pagamento da conservação das áreas naturais locais, dos sítios arqueológicos e históricos, das artes, dos artesanatos, das tradições culturais e também contribuir para a melhoria geral da qualidade ambiental, pois esses são atrativos para os turistas".

A prática do turismo sustentável pressupõe o uso responsável dos atrativos turísticos e, por conseguinte do patrimônio cultural, em uma abordagem mais ampla, 
visa promover a harmonia dos seres humanos entre si, com a natureza e com o patrimônio. Utilizar o patrimônio natural e cultural de forma sustentável representa a promoção do turismo viável, ético e principalmente responsável.

PORTUGUEZ (2004, p. 08), ressalta que "o patrimônio refere-se às pessoas, às origens e à história de uma comunidade. Prega-se aqui a necessidade de preservar o patrimônio para reforçar a identidade das pessoas e dos lugares em primeiro lugar e, se houver potencial turístico, sua utilização recreacional".

Contudo, é importante observar que essa utilização 'recreacional' do patrimônio cultural para fins turísticos deve ser bem planejada e organizada, seguindo os princípios norteadores do desenvolvimento sustentável, visando a preservação da cultura, do patrimônio da localidade.

Miguel Ángel Troitiño Vinuesa comenta que "uma estratégia verdadeiramente inovadora de conservação e administração do patrimônio cultural deve partir, obrigatoriamente, de uma concepção ampla deste, apostando em uma adequação respeitosa para o uso turístico". (apud PORTUGUEZ: 2004, p. 41).

Nesse sentido, é notório que o turismo a que Vinuesa se refere é o turismo responsável, preocupado com a conservação do patrimônio, a capacidade de carga da localidade, planejado e organizado de forma a minimizar os impactos negativos e ampliar o conhecimento a respeito da cultura de cada localidade, o turismo cultural, o turismo de conhecimento, nunca o turismo de massa.

Entretanto, o turismo de massa cresce de forma exorbitante, um turismo sem planejamento, sem preocupação, com objetivo de satisfazer as necessidades do 
turista e gerar lucro em curto prazo, contudo, ninguém parou para refletir a respeito de suas conseqüências a médio e longo prazo.

O turismo de massa, de forma nenhuma pode ser caracterizado como uma prática sustentável, pois não é comprometido com as causas naturais e culturais, é apenas uma modalidade de turismo como atividade comercial.

Célia Maria Perdigão Coutinho ${ }^{1}$ comenta que "as práticas de conservação do patrimônio muitas vezes quando se apóiam no turismo de larga escala, têm trazido preocupações pelas possibilidades de promover a distribuição do próprio objeto".

Vera Sylvia de Matos Dourado Mamede (apud MARTINS, 2003, p. 37), comenta que "sendo o turismo uma fonte alternativa para a economia local, faz-se necessário um planejamento sério e cuidadoso, pois como vem sendo implementado e incentivado, tem trazido resultados sustentados imediatos e, mesmo assim, nem para todos da localidade, e longe está de colaborar com a sustentabilidade desses lugares".

Contudo, para que o processo de desenvolvimento sustentável do turismo se implante é necessário planejamento integrado, mobilização social, a participação comunitária, cooperação, flexibilidade, articulação política, sinergia de decisões. O processo envolve cultura, ambiente, portanto pessoas, além das relações de diversas culturas e pessoas com o ambiente. Sendo assim, o turismo é capaz de desencadear um processo de promoção cultural, salientando a diversidade social, valorizando os saberes, conhecimentos, práticas e valores éticos das populações diversas e incluindo essas populações na economia.

\footnotetext{
${ }^{1}$ Célia Maria Perdigão Coutinho, artigo publicado na Revistal Virtual de Educação Patrimonial, disponível em www.educacaopatrimonial.com.br, acessado em março de 2007.
} 
A OMT (2001, p. 246) ressalta que "o desenvolvimento do turismo sustentável pode suprir necessidades econômicas, sociais e estéticas, se mantêm íntegra a cultura e os processos ecológicos. Esse tipo de turismo pode trazer benefícios às gerações presentes sem diminuir as possibilidades de obtenção de benefícios para as gerações futuras".

A manutenção da diversidade, a preservação da cultura, a valorização dos conhecimentos, dos saberes, das práticas peculiares das comunidades, a inclusão dessas comunidades no processo de desenvolvimento do turismo sustentável são ações que fomentam e alavancam o estabelecimento de uma sociedade sustentável e produtiva, capaz de usufruir e preservar suas riquezas e não apenas acumular lucro.

Portanto, o desenvolvimento do turismo sustentável ultrapassa a barreira de uma atividade simplesmente comercial, considerando também e com muita propriedade o caráter social do turismo.

IRVING (2002), comenta que "o desenvolvimento da atividade turística qualificada de sustentável exige a incorporação de princípios e valores éticos, uma nova forma de pensar a democratização de oportunidades e benefícios e um novo modelo de implementação de projetos, centrado em uma parceria, coresponsabilidade e participação".

Através do turismo sustentável, é possível tornar a vida em sociedade mais justa, com trabalho, educação, instrução, participação e liberdade, gerando melhorias para todos os atores sociais envolvidos no processo, como a melhoria na qualidade de vida, na distribuição de renda, sendo assim agente de inclusão social. 
Mais do que isso, o turismo sustentável configura-se como incentivo ao conhecimento e valorização do patrimônio cultural, histórico e natural, proporcionando a preservação de costumes locais e resgatando suas tradições, suas manifestações, bem como as músicas, danças, o artesanato, enfim, a cultura popular. 


\section{O PATRIMÔNIO}

\subsection{DISCUTINDO O CONCEITO}

Muitas utilizações são atribuídas à palavra patrimônio, cada uma assumindo um sentido peculiar. A palavra surge com a intenção de designar herança familiar, relacionando-se principalmente aos bens materiais.

Nesse sentido, FERREIRA (1989, p. 379) define como patrimônio "herança paterna, bens de família, riqueza, bens materiais ou não de uma pessoa ou empresa".

No século XVIII, começaram na Europa as primeiras medidas para a proteção de monumentos de valor histórico, onde a expressão 'patrimônio' passou a ser utilizada para denominar os bens salvaguardados por lei e pelos órgãos constituídos para tal função.

No século XIX, intensificou-se a criação de patrimônios nacionais, com o intuito de criar referências de importância comum a todos os que habitam determinado território, criando conseqüentemente tradições comuns, uma língua e uma história nacional que se sobrepõe às memórias regionais e particulares, dessa forma o patrimônio passou a ser uma construção social de altíssima importância política, uma escolha oficial de representação de um passado histórico de uma sociedade.

Segundo informações disponíveis na página eletrônica do Instituto do Patrimônio Histórico e Artístico Nacional - IPHAN, o patrimônio cultural não é restrito apenas a igrejas, palácios e imóveis oficiais isolados, na sua concepção contemporânea, o patrimônio se estende a trechos urbanos, imóveis particulares e 
até mesmo ambientes naturais de importância paisagística, passando por imagens, mobiliário, utensílios e outros bens móveis.

A diversidade natural de nosso país e nossos trechos rurais, protegidos, conservados, preservados e salvaguardados pelo Ministério do Meio Ambiente MMA e pelo Instituto Brasileiro do Meio Ambiente e dos Recursos Naturais Renováveis - IBAMA, através do Sistema Nacional de Unidades de Conservação SNUC, também constituem o nosso patrimônio, contudo, não serão abordados neste trabalho, onde o enfoque principal será para o patrimônio cultural.

O Patrimônio Cultural Brasileiro foi subdividido pelo IPHAN em Patrimônio Cultural Imaterial e Patrimônio Cultural Material. De acordo com a Organização das Nações Unidas para a Educação, a Ciência e a Cultura - Unesco em textos disponíveis em seu endereço eletrônico, Patrimônio Cultural Imaterial é definido como as expressões, as práticas, as representações, os conhecimentos e técnicas, também os instrumentos, objetos, artefatos e lugares que lhes são associados e as comunidades, os grupos e, em alguns casos, os indivíduos que se reconhecem como parte integrante do seu patrimônio cultural.

O Patrimônio Imaterial é transmitido através das gerações, porém, passa por constantes recriações em função do ambiente a que fazem parte, de sua interação com a natureza e de sua história, gerando assim identidade e continuidade, contribuindo para promover o respeito à diversidade cultural e à criatividade humana.

O Patrimônio Material, protegido pelo IPHAN está subdividido e classificado de acordo com a natureza que fazem parte, podendo ser paisagístico, arqueológico 
e etnográfico; histórico; de belas artes; e das artes aplicadas. Eles estão divididos em bens imóveis como os núcleos urbanos, bens individuais e os sítios arqueológicos e paisagísticos; e bens móveis como coleções arqueológicas, acervos museológicos, documentais, bibliográficos, arquivísticos, videográficos, fotográficos e cinematográficos.

HORTA $^{2}$ (2003), em seu texto sobre educação patrimonial para o programa Salto para o futuro da TV Escola, TVE Brasil, comenta que existem ainda outras formas de expressão cultural que constituem o patrimônio vivo da sociedade brasileira como o artesanato, a culinária, maneiras de pescar, caçar, plantar, cultivar e colher, de utilizar plantas como medicamentos e alimentos, de fabricar objetos de uso e construir moradias, as danças e músicas, os modos de vestir e falar, as relações sociais e familiares, os rituais e festas religiosas e populares, as canções, as histórias e lendas contadas de geração em geração, revelando os vários aspectos que pode assumir a cultura viva e presente em uma comunidade.

O Patrimônio Cultural compreende os elementos de caráter significativo no que diz respeito à memória social de uma população, grupo ou nação. Sendo estes elementos naturais, do meio ambiente, o produto intelectual acumulado pelo homem no decorrer de sua história e bens culturais em formas concretas, resultante da capacidade de sobrevivência do homem em meio ao ambiente.

Portanto, o Patrimônio Cultural caracteriza-se como a essência humana expressada em sua produção, seja de ordem intelectual, emocional, imaterial ou material, independentemente de época, origem, natureza ou aspecto formal.

\footnotetext{
${ }^{2}$ Maria de Lourdes Parreiras Horta em Boletim sobre Educação Patrimonial para o Programa Salto para o futuro da TV Escola, TVE Brasil, disponível em www.tvebrasil.com.br/salto/boletim2003, acessado em março de 2007.
} 
O Patrimônio Cultural é o testemunho da identidade e da diversidade cultural das comunidades em diferentes épocas, gerador de memórias históricas que são conservadas e transmitidas às gerações permitindo assim que possam usufruir do legado e conseqüentemente das tradições das gerações anteriores e preservar para as próximas gerações, não apenas pelo simples fato de conservar as tradições, mas por elas serem parte importante na vida e na dinâmica de cada comunidade.

Mariza Veloso observa que "as tradições manifestam-se através de práticas coletivas concretas que se inscrevem no cotidiano dos grupos sociais, definindo as marcações do tempo e do espaço e , principalmente, construindo as referências de lugar.", referências estas que representam a identidade cultural de uma comunidade e por conseguinte seu patrimônio (apud TEIXEIRA, et al : 2004, p.32).

Sobre identidade cultural e patrimônio, Marta Arjona (1986, p.11), comenta que "a identidade cultural está expressada como uma conseqüência e não como um objeto em si, que a soma dos bens culturais acumulados de modo voluntário por uma comunidade conforma seu patrimônio cultural, e que a conseqüência social dele é a identificação desse conjunto heterogêneo com esse grupo de homens. Resulta então que, em princípio, a identidade cultural se produz através do patrimônio e como conseqüência dele."

Assim, a relação existente entre patrimônio e a identidade cultural se torna cada vez mais explícita, uma relação de pertencimento, um vínculo histórico, cultural, social, de costumes e tradições de uma sociedade, seus modos de pensar e agir, de um tempo, de uma época. 
Contudo, o significado que é atribuído ao patrimônio é mutante, transforma-se de acordo com o momento em que vivemos, as memórias e as necessidades de nossa sociedade, em virtude a dinâmica do processo de construção cultural, onde os valores, as tradições se flexibilizam para atender as novas necessidades da população. $\mathrm{Na}$ atualidade, conseguimos entender que o patrimônio não se resume apenas a memórias, mas também a percepção de experiências, ao pertencimento a um conjunto, ao compartilhamento de um espaço, a uma mesma cultura, compondo assim uma identidade e uma memória coletiva.

Ainda Mariza Veloso, ressalta que "a memória coletiva permite entrelaçar experiências diversas no tempo e no espaço, transformando a tradição em fonte de reposição de sentido, e imprimindo vida e historicidade às práticas culturais. Estas, por sua vez, transformam o bem cultural em matéria viva, e mais do que isto, passam a considerar o bem cultural não como produto, mas como processo construído a partir de uma criação permanente, onde os indivíduos são chamados a participar do conhecimento e reconhecer sua própria cultura" (apud TEIXEIRA, et al : 2004, p.33).

De uma forma geral podemos dizer que as riquezas, as tradições culturais, os saberes e fazeres de uma determinada população constituem seu patrimônio cultural, e que através desse patrimônio pode-se identificar traços culturais típicos e, por conseguinte a cultura de determinada comunidade, haja vista que o patrimônio cultural é a representação da peculiaridade, singularidade, particularidade e individualidade de uma comunidade.

Cecília Londres, defende que "é preciso 'abrir' a noção de patrimônio, de modo que possa englobar as tradições mais diversas, tudo enfim que os diferentes 
grupos sociais considerem como uma herança significativa a ser transmitida para as futuras gerações" (apud TEIXEIRA, et al: 2004, p. 21).

Desta forma o patrimônio cultural deixou de ser interpretado apenas pelos prédios e utensílios utilizados pela elite econômica e política, e passou a ser definido como um conjunto de todos os utensílios, hábitos, crenças, usos e costumes, além da forma de vida cotidiana de todos os segmentos que compõem a sociedade, como observa BARRETO (2000).

Ana Gita de Oliveira observa que "o patrimônio deva ser visto a partir de um campo de significados, de um conjunto de densidades simbólicas específicas, de modo que temas correlatos como memória, cultura popular, folclore, arqueologia, etc possam ser entendidos como elementos constitutivos do patrimônio" (apud TEIXEIRA, et al : 2004, p.38).

Assim, a complexidade do patrimônio torna-se muito mais abrangente do que o que está contemplado no texto do Decreto-lei oㅡ 25, promulgado no Brasil em 1937, que classifica o patimônio cultural como sendo o "conjunto de bens móveis e imóveis existentes no país, cuja conservação seja de interesse público, quer por sua vinculação a fatos memoráveis, quer pelo seu excepcional valor arqueológico, etnológico, bibliográfico ou artístico".

O Patrimônio Cultural é muito mais do que um texto de um Decreto-lei, ou de uma convenção, é a forma mais genuína da representação dos hábitos, costumes, crenças, crenças, tradições, expressões de uma população, além de edificações, documentos, utensílios que tenham significativa importância para determinada comunidade e que assim sejam capazes de gerar uma identificação e uma sensação 
de pertencimento entre o bem e a comunidade, nascendo então a vontade e a necessidade de preservação.

ASSUNÇÃO (2003, p. 23) comenta que "chamamos de patrimônio o conjunto de bens culturais de propriedade de todos os cidadãos e que tenham valor reconhecido para uma região e humanidade. Define-se bens culturais como a produção cultural dos indivíduos nas diferentes partes do mundo formando o testemunho da intervenção humana no ambiente englobando as mais diversas formas".

A Constituição Brasileira de 1988 trata do Patrimônio Cultural Brasileiro em seu artigo 216:

Constituem patrimônio cultural brasileiro os bens de natureza material e imaterial, tomados individualmente ou em conjunto, portadores de referência à identidade, à ação, à memória dos diferentes grupos formadores da sociedade brasileira, nos quais se incluem:

I - as formas de expressão;

II - os modos de criar, fazer e viver;

III - as criações científicas, artísticas e tecnológicas;

IV - as obras, objetos, documentos, edificações e demais espaços destinados às manifestações artístico-culturais;

V - os conjuntos urbanos e sítios de valor histórico, paisagístico, artístico, arqueológico, paleontológico, ecológico e científico.

Portanto, o Patrimônio Cultural é a junção de expressões, objetos, formas de criar e de viver que tenham significativo valor histórico, estético, simbólico, artístico, cultural, científico, tecnológico, de natureza material ou imaterial, apresentado de 
forma individual ou coletiva, que seja capaz de representar fatos, momentos, épocas importantes, a identidade cultural do grupo a que representa.

É importante ressaltar que os trechos rurais, que também constituem o patrimônio nacional não foram incorporados no Artigo 216 da Constituição Brasileira de 1988, assim como também não são contemplados como patrimônio pelo IPHAN, que trata apenas dos trechos e conjuntos urbanos.

PAOLI (1992, p. 25), observa que "a noção do patrimônio histórico deveria contemplar múltiplas dimensões da cultura como imagem de uma passado vivo, gerando a consciência de preservação pela significatividade coletiva dos fatos".

Segundo CHOAY (2001), a expressão 'patrimônio' é utilizada hoje em dia para caracterizar um bem destinado ao usufruto de uma comunidade, constituído pela acumulação diversificada de objetos de passado comum, de trabalhos que contemplem todos os saberes, costumes, crenças, edificações, tudo o que representa importância, pertencimento a determinado grupo, tudo que uma população reconhece como sua história, sua vida e que por se sentir parte desse patrimônio passa a atribuir valor e conseqüentemente desenvolve a vontade e a necessidade de conservá-lo.

Cecília Londres, ressalta que "a atribuição de valor de patrimônio a um bem cultural pressupõe uma sedimentação de significados, algum grau de consumo quanto à atribuição dessa distinção e um interesse em 'preservar' esse bem, seja lá o que se entenda por isso" (apud TEIXEIRA, et al : 2004, p.19).

No entanto, cabe aqui observar que no presente trabalho a questão da preservação está sendo interpretada como a vontade e a ação de manter vivos os 
bens culturais, conservando suas peculiaridades, com a intensão de manter a cultura, a história.

No que se refere a preservação, LEMOS $(1987$, p. 29) observa que "preservar não é só guardar uma coisa, um objeto, uma construção, um miolo histórico de uma cidade, é também manter vivos, mesmo que alterados, os usos e costumes populares".

Portanto, é indispensável conservar os valores que representam importância singular na dinâmica de uma sociedade, sejam estes valores, bens culturais de qualquer natureza, desde que tenham importância e significatividade para o grupo a que representa.

Mariza Veloso acrescenta que "o reconhecimento e a vivência do patrimônio podem ainda, transformá-lo em força produtiva na promoção de uma vivência também coletiva, ensejando a construção de experiências significativas capazes de motivar o sentido de pertencimento", criando assim uma cumplicidade e um comprometimento entre a comunidade e seu patrimônio, além da vontade de salvaguardá-lo para manter viva sua história, sua identidade (apud TEIXEIRA, et al : 2004, p.33).

Machado \& Ataídes (1998, p. 42) comenta que "a identidade tem como suporte fundamental a memória, mecanismo de retenção de informação, conhecimento, experiência em nível individual e social, sendo eixo de atribuições, que articula e categoriza os aspectos multiformes de realidade, dando-Ihes lógica e inteligibilidade", sendo assim a identidade cultural de uma comunidade o aspecto marcante de seu patrimônio. 
Portanto, patrimônio é muito mais do que um simples objeto ou um prédio histórico ou uma paisagem natural, patrimônio é toda a interação que existe entre as comunidades e o meio a que elas fazem parte, patrimônio é a história, a cultura, a vivência, os costumes, as tradições, os hábitos, as crenças, o folclore. Patrimônio é a forma de falar, de vestir-se, de pensar, de agir de um povo, suas lendas, ritos, festas populares e religiosas, suas danças, músicas e canções. Patrimônio são as relações sociais e familiares, as relações com o ambiente, as memórias e experiências de uma comunidade, sua cultura e identidade, além dos bens materiais como prédios históricos, documentos e utensílios, portanto a preservação desse patrimônio é muito mais do que um ato conservacionista e sim a oportunidade da sociedade entender sua existência.

\subsection{A EDUCAÇÃO PATRIMONIAL}

De acordo com a Lei ํㅜ $9.394^{3}$ de 20 de Dezembro de 1996, sobre as Diretrizes e Bases da Educação Nacional, em seu Art. 1ํㅜ consta que "a educação abrange os processos formativos que se desenvolvam na vida familiar, na convivência humana, no trabalho, nas instituições de ensino e pesquisa, nos movimentos sociais e organizações da sociedade civil e nas manifestações culturais".

A mesma lei trata ainda em seu Artigo 26 sobre os currículos do ensino fundamental e médio, que "devem ter uma base nacional comum, a ser contemplada, em cada sistema de ensino e estabelecimento escolar, por uma parte diversificada, exigida pelas características regionais e locais da sociedade, da cultura, da economia e da cultura".

\footnotetext{
${ }^{3}$ Lei n 9.394 de 20 de Dezembro de 1996, disponível em: www.planalto.gov.br, acessado em março de 2007.
} 
Assim, a educação formal brasileira, flexibiliza sua grade curricular de acordo com a cultura, os costumes, a economia de cada localidade, possibilitando assim o estudo e o entendimento da diversidade cultural de nosso país.

O Ministério da Educação, em virtude da diversidade cultural Brasileira desenvolveu Parâmetros Curriculares Nacionais - PCN, com a intenção de adequar o sistema de ensino de cada região à sua realidade. Não se trata de obrigações a serem cumpridas pelas instituições de ensino, trata-se de sugestões norteadoras para a melhoria do processo ensino/aprendizagem e conseqüentemente para a formação de cidadãos, segundo POSSATI ${ }^{4}$.

Os Parâmetros Curriculares Nacionais, de acordo com as considerações de MAGALHÃES (2005), permitem a interdisciplinaridade na educação através da introdução de 'temas transversais', temas estes que tratam de processos que estão sendo intensamente vividos pela sociedade, pelas comunidades, como meio ambiente e pluralidade cultural articulados as diferentes disciplinas escolares, possibilitando assim o estudo do patrimônio histórico e cultural, logo a educação patrimonial, contemplando a diversidade, salvaguardando a identidade de cada comunidade.

Dessa forma, através dos temas transversais propostos pelos Parâmetros Curriculares Nacionais, para a adequação da educação básica brasileira à realidade de cada região, podemos implementar ações que contemplem o conhecimento do patrimônio cultural de cada localidade, incentivando a consciência cidadã, fazendo assim o que se entende por educação patrimonial.

\footnotetext{
${ }^{4}$ José Antônio Possati em seu artigo Turismo e Educação Ptrimonial publicado na Revista Virtual Educação Patrimonial, disponível em: www.educacaopatrimonial.com.br, acessado em abril de 2007.
} 
A expressão 'Educação Patrimonial', interpretada como uma metodologia para o desenvolvimento de ações educacionais foi introduzida no Brasil a partir do $1^{\circ}$ Seminário sobre o Uso Educacional de Museus e Monumentos e o $1^{\circ}$ Seminário de Educação Patrimonial, realizados em 1983, de acordo com HAIGERT (2003). Com o passar do tempo a educação patrimonial tornou-se bastante evidente, configurandose como uma prática muito conhecida desde 1997 em cidades onde o IPHAN mantém áreas tombadas, reconhecidas como patrimônio nacional, com a intensão de envolver as comunidades na conservação do patrimônio cultural.

De acordo com o $2^{\circ}$ Caderno da Série Cultura do Governo do Estado de Minas Gerais (2001, p. 29):

"a educação patrimonial constitui prática de ensino e aprendizagem que prioriza as relações socioculturais e utiliza como recurso básico de instrução a evidência material da cultura ou seus pontos de referência tangíveis. Favorece o senso de conexão e continuidade com nossa herança histórica e cultural, fornecendo elementos para a compreensão do processo de construção dos valores que norteiam o nosso presente, enriquecendo com este conhecimento as perspectivas para o futuro. A Educação Patrimonial promove ainda, o reconhecimento e a valorização da diversidade cultural, ampliando, em paralelo, o reconhecimento do outro e de si próprio, aproximando as pessoas do entendimento mútuo e desenvolvendo $o$ senso de respeito $e$ responsabilidade pelo bem comum, construindo assim a consciência cidadã."

Portanto, a educação patrimonial é uma proposta de educação interdisciplinar, que tem por intenção, além de informar sobre a existência de um patrimônio cultural, incentivar a sensibilidade da população a respeito de sua história, sua cultura, seu patrimônio, através de atividades lúdicas, como jogos, peças teatrais, desenhos, produção de poesias, músicas, além de exposições e palestras com o propósito de reconhecer e valorizar a cultura de cada localidade. 
FREIRE (1996, p. 34) comenta:

"A Educação Patrimonial pode aplicar uma metodologia específica para a 'leitura do mundo' e das coisas produzidas pelo indivíduo em sua vida cotidiana, a 'alfabetização cultural' capacita o aprendiz, enquanto cidadão, a melhor entender sua identidade cultural e a se apropriar afetiva e conscientemente de seus valores e marcas, próprias do patrimônio pessoal e coletivo".

Contudo, para que as pessoas possam conservar sua história e sua identidade cultural é necessário conhecer seu passado, valorizar sua cultura, seus costumes, ter consciência sobre a importância do patrimônio para a conservação da diversidade e a sustentabilidade da cultura e a sensibilização para a cidadania.

Horta (1999, p. 06), acrescenta que a "Educação Patrimonial é um trabalho educacional permanente e sistemático, centrado no patrimônio cultural como fonte primária de conhecimento e enriquecimento individual e coletivo. O conhecimento crítico e a apropriação consciente pelas comunidades do seu patrimônio são fatores indispensáveis no processo de preservação sustentável desses bens, assim como no fortalecimento dos sentimentos de identidade e cidadania".

BARRETO (2000, p. 46), observa que "manter algum tipo de identidade étnica, local ou regional - parece ser essencial para que as pessoas se sintam seguras, unidas por laços extemporâneos a seus antepassados, a um local, a uma terra, a costumes e hábitos que Ihes dão segurança, que lhes informam quem são e de onde vêm".

Diante de tais considerações, torna-se cada vez mais aparente a necessidade e a importância da implantação de projetos que contemplem a educação patrimonial, capazes de instigar a comunidade a conhecer melhor seu patrimônio, aceitando e 
valorizando seus bens culturais, conseqüentemente preservando e mantendo-os não apenas para as próximas gerações, mas também para suprir a necessidade de identificação entre o homem e sua produção, sua cultura, seu patrimônio, entendendo assim a relação de pertencimento homem e patrimônio.

A Equipe de Educação Patrimonial responsável pelo programa Trens de Minas do Instituto Estadual do Patrimônio Histórico e Artístico de Minas Gerais IEPHA/MG, considera que a "educação patrimonial busca agregar valores culturais e históricos, estabelecendo laços sociais para criar, assim, um possível desenvolvimento sustentável das regiões. Essa proposta (incluída no âmbito da educação, em sentidos mais amplos: formal e informal e os dois concomitantemente) terá como base a conquista de um significado de preservação patrimonial pela própria comunidade atendida, justificando-se pela possibilidade, a partir da sua difusão, da construção de um projeto mais amplo de cidadania e de responsabilidade social".

Horta (1999, p. 06) comenta que a "educação patrimonial é um instrumento de ‘alfabetização cultural' que possibilita ao indivíduo fazer a leitura do mundo que o rodeia, levando-o a compreensão do universo sócio-cultural e da trajetória histórico temporal em que está inserido. Este processo leva ao reforço da auto-estima dos indivíduos e comunidades e à valorização da cultura".

"O desenvolvimento de programas de Educação Patrimonial, envolvendo não só a rede escolar, mas a comunidade, as famílias, empresas, proposta para ser explorada na educação de crianças e adultos, inserida nos currículos e disciplinas do sistema formal de ensino como instrumento para a prática da cidadania e o 
estabelecimento de um diálogo entre gerações" de acordo com MAGALHÃES (2005, p. 18).

Diálogo este que só pode ser estabelecido através do estudo, do conhecimento, do acompanhamento da história, das memórias, da cultura, dos costumes de uma população, da análise crítica e responsável das modificações sofridas com o passar do tempo, para a manutenção da identidade cultural.

Contudo, é de importância fundamental enfatizar que a conservação do patrimônio cultural é o enfoque principal da educação patrimonial, para isto é necessário conhecer, entender e valorizar, para conseqüentemente criar consciência crítica e responsável, comprometida não apenas com a conservação de um bem cultural, mas com a conservação dos valores culturais e históricos de uma população.

Em artigo publicado na Revista Educação Patrimonial ${ }^{5}$, em outubro de 2006, os autores comentam que "a educação patrimonial tem como um de seus objetivos a construção da identidade do indivíduo através desses patrimônios, levando-o a uma reflexão sobre a prática da cidadania".

A educação patrimonial é uma forma de construção da cidadania, através dela é possível demonstrar a importância da preservação do patrimônio e principalmente a importância do próprio patrimônio em função de sua pluralidade, para a manutenção da diversidade cultural de um grupo social.

\footnotetext{
${ }^{5}$ Revista Virtual Educação Patrimonial, disponível em: www.educacaopatrimonial.com.br, acessado em março de 2007.
} 
Maria de Lourdes Parreiras Horta ${ }^{6}$ observa que "o desenvolvimento de programas de educação patrimonial contribui para uma nova visão do patrimônio cultural brasileiro, salientando a diversidade de manifestações, tangíveis e intangíveis, materiais e imateriais como fonte de conhecimento e aprendizado e instrumento de motivação individual e coletiva".

A educação patrimonial, além de tudo o que foi discutido anteriormente, configura-se como uma forma de resgatar a relação de afeto, apego, amor, identificação entre a comunidade e seu patrimônio, desencadeando um processo de aproximação do bem cultural à população, enfatizando o sentimento de pertencimento, compreendendo o patrimônio como sua história, sua cultura, sua memória.

Contudo, mesmo sendo a educação patrimonial considerada de importância fundamental para a conservação do patrimônio cultural de nosso país e conseqüentemente para a manutenção de nossa história, ainda assim não é tratada com a devida propriedade no que diz respeito ao ensino básico e médio da educação brasileira, onde deveria estar contemplada e articulada com o ensino de história e geografia, ou até mesmo como uma disciplina específica, capaz de atribuir o valor merecido aos conteúdos relativos à cultura nacional.

Portanto, é de importância fundamental ressaltar que a preservação do patrimônio depende do conhecimento e de uma educação voltada para a compreensão e valorização da diversidade, entretanto essa educação tem que ser implementada em todas as escolas, sejam elas públicas ou privadas, com a intenção

\footnotetext{
${ }^{6}$ Maria de Lourdes Parreiras Horta em Boletim para o Programa Salto para o futuro da TV Escola, TVE Brasil, disponível em: www.tvebrasil.com.br/salto/boletim2003, acessado em março de 2007.
} 
de a médio e longo prazo termos consciência a respeito de nosso patrimônio e conseqüentemente a vontade de preservá-lo.

Entretanto, a educação patrimonial é uma ferramenta indispensável no processo de preservação do patrimônio, mais do que isso, sua representatividade na construção da consciência cidadã é imensurável, sendo capaz de despertar em cada indivíduo a sensibilidade e a mobilização em relação a preservação.

\subsection{PATRIMÔNIO CULTURAL E TURISMO}

O Turismo, dependendo da forma como é planejado e conseqüentemente desenvolvido, constitui uma atividade econômica capaz de auxiliar na obtenção de resultados de altíssima relevância no que diz respeito à preservação da história, da memória, do patrimônio, da identidade cultural de um povo, além de proporcionar o bem-estar dos envolvidos.

RABAHY (2003, p. 84), comenta que "o turismo é uma das atividades integrantes da política de valorização do bem-estar, que deve incorporar a conservação dos recursos naturais e do patrimônio sociocultural".

Já POSSATI7 observa que "mais do que uma atividade econômica lucrativa do terceiro setor, o turismo tem se apresentado como um fenômeno social, capaz de promover a interação entre diferentes culturas e povos. Enquanto ferramenta mitigadora das desigualdades sociais, o turismo proporciona subsídios à

\footnotetext{
${ }^{7}$ José Antônio Possati em seu artigo Turismo e Educação Patrimonial publicado na Revista Virtual Educação Patrimonial, disponível em: www.educacaopatrimonial.com.br, acessado em abril de 2007.
} 
manutenção, recuperação e/ou disseminação da cultura popular, beneficiando o lugar, o visitante e o visitado".

De acordo com a Organização Mundial do Turismo - OMT(1980), citado por IRVIN (2002), "o gerenciamento racional do turismo pode contribuir de forma significativa para a proteção e o desenvolvimento do ambiente físico e do patrimônio cultural como também à melhoria da qualidade de vida, ..., o turismo aproxima as pessoas e cria consciência sobre as diversas formas de vida, tradições e aspirações".

A relação estabelecida entre turismo e patrimônio é bastante estreita, pois cada vez mais as pessoas têm buscado, através do turismo cultural, de conhecimento e de lazer, certo crescimento cultural, em virtude da apreciação das culturas peculiares, do patrimônio arquitetônico, histórico, natural e religioso dos locais visitados.

O turismo cultural gera vantagens econômicas e sociais significativas no que diz respeito ao crescimento local. Os bens materiais e imateriais desempenham papel importante na promoção do turismo e, conseqüentemente, as medidas que levam à sua preservação e a adequada utilização têm relação com a manutenção da atividade turística, haja vista que o turismo se utiliza dos bens patrimoniais de forma responsável e sustentada.

Antônio Pereira de Oliveira (apud VELOSO, 2003, p. 14), comenta que o "o turismo cultural é aquele praticado por professores, técnicos, pesquisadores, arqueólogos, cientistas, estudantes em busca de novos conhecimentos". 
Entretanto, o turismo cultural não se resume a esta definição citada anteriormente, o turismo cultural é muito abrangente, pode ser praticado por qualquer indivíduo que demonstre vontade de adquirir conhecimento, vivenciar culturas novas, contemplar os elementos significativos que compõem o patrimônio histórico e cultural dos mais diversos grupos que integram uma sociedade.

O desenvolvimento do turismo cultural está diretamente ligado ao esforço de se preservar os valores culturais. É de fundamental importância que todos assumam uma postura de responsabilidade, comprometida com a vinculação dos conceitos de desenvolvimento sustentável do turismo e sua relação direta com a preservação do patrimônio.

O patrimônio cultural é o protagonista dos projetos de turismo cultural, portanto sua conservação é indispensável, entretanto, ainda existem pessoas que desconhecem a importância do patrimônio que detêm, as vezes por falta de acesso a meios que possibilitem este tipo de informação.

Dessa forma, cabe ressaltar que o turismo configura-se justamente como uma ferramenta de importância fundamental no que se refere a proteção, conservação e salvaguarda do patrimônio cultural, além de um excelente meio de informação a respeito desse patrimônio.

Sobre essa questão, BARRETO ( 2001, p. 104) ressalta que "a preservação do patrimônio pode ser tanto causa como conseqüência do turismo".

Contudo, essa relação entre o patrimônio e o turismo ainda não é pensada com a devida importância. Justamente pelo fato de o patrimônio ser visto como um 
bem a ser preservado e o turismo uma atividade econômica meramente exploratória e geradora de renda. 


\section{TURISMO E PATRIMÔNIO: O OLHAR DO PODER PÚBLICO}

\subsection{O Plano Plurianual 2004-2007 - PPA}

O Plano Plurianual - PPA é um instrumento de organização das ações do Governo, uma espécie de planejamento para a realização de programas, projetos e metas em um quadriênio, nesse caso 2004-2007, no âmbito da Administração Pública Federal.

PPA 2004-2007(2003, p. 20):

"O PPA 2004-2007 tem por abjetivo inaugurar a seguinte estretégia de longo prazo: inclusão social e desconcentração de renda com vigoroso crescimento do produto e do emprego; crescimento ambientalmente sustentável, redutor das disparidades regionais, dinamizado pelo mercado de consumo de massa, por investimentos e por elevação da produtividade: redução da vulnerabilidade externa por meio da expansão das atividades competitivas que viabilizam esse crescimento sustentado; e fortalecimento da cidadania e da democracia".

Nesse sentido, a análise do Plano Plurianual Brasileiro nos possibilita entender de qual forma o turismo e o patrimônio são pensados na esfera pública federal, qual tipo de interpretação é atribuída a esses termos e os programas, projetos e ações que estão sendo planejados para esses segmentos.

Programa: Artesanato Brasileiro

Objetivo: Fortalecimento da competitividade do produto artesanal para a geração de trabalho e renda e incentivo a sua exportação

Público-alvo: Artesãos

Atividades:

Capacitação de Artesãos e Multiplicadores;

Estruturação de Núcleos Produtivos do Segmento Artesanal;

Feiras e Eventos para Comercialização da Produção Artesanal;

Gestão e Administração do Programa;

Rotas de Artesanato e Turismo.

(PPA 2004-2007: 2003, vol. II, p. 41). 
Um programa aparentemente simples, entretanto é bastante complexo, pois além de incentivar o artesanato das regiões, resgatando através desse incentivo, da capacitação e da formação de agentes multiplicadores dessa cultura, a perpetuação dos costumes da localidade, além de mostrar que esse artesanato em conjunto com a atividade do turismo é capaz de ser uma fonte alternativa de renda, e uma divulgação da cultura popular brasileira no exterior.

Contudo, o programa não mostra explicitamente a questão do resgate da cultura e conseqüentemente sua preservação com o passar dos anos, enfoca principalmente a questão econômica do artesanato brasileiro e sua associação à atividade turística.

Programa: Brasil Patrimônio Cultural

Objetivo: Preservar e revitalizar o patrimônio cultural brasileiro Público-alvo: Sociedade Projetos:

Ampliação e Modernização de Laboratórios de Preservação da Fundação Casa de Rui Barbosa;

Reabilitação de Sítios Históricos Protegidos;

Reforma do Complexo Museu Botânico e Biblioteca do Instituto de Pesquisas Jardim Botânico do Rio de Janeiro;

Reforma do Prédio do Museu-Sítio Casa dos Pilões.

\section{Atividades:}

Acautelamento de Bens Culturais;

Ampliação dos Acervos Documentais do Patrimônio Cultural; Capacitação de Recursos Humanos na Área de Patrimônio Cultural; Concessão de Prêmios na Área de Patrimônio Cultural; Educação Patrimonial em Áreas de Bens Culturais; Fomento a Projetos na Área de Patrimônio Cultural de Natureza Material; Gestão e Administração do programa; Identificação e Inventário de Bens do Patrimônio Cultural; Implantação de Sinalização em Sítios Históricos e Arqueológicos; Inspeção Técnica e Fiscalização de Bens Protegidos; Pesquisa de Depósitos Fossíferos; Pesquisa sobre Preservação do Patrimônio Cultural; Preservação de Acervos Culturais; Prservação de Acervos Históricos, Administrativos e Artísticos; 
Preservação de Bens Imóveis do Patrimônio Histórico e Cultural;

Preservação de Bens Paisagísticos, Arqueológicos e Imóveis do Patrimônio Histórico e Artístico;

Preservação dos Acervos Documentais Privados de Presidentes da República;

Produção e Distribuição de Material sobre o Patrimônio Cultural;

Promoção e Intercâmbio de Eventos na Área do Patrimônio Cultural;

Resgate da Documentação Histórica do Brasil Existente no Exterior.

Operações Especiais:

Apoio à Proteção do Patrimônio Histórico Nacional contra Desastres. (PPA 2004-2007: 2003, vol. II, p. 84).

Programa este de importância fundamental para a conservação da cultura de nossa população. Contempla o patrimônio cultural de forma total, desde a sua conservação até sua revitalização, mostrando a necessidade de se implantar a Educação Patrimonial para de fato conseguirmos chegar a preservação de nossa cultura, nossos bens culturais, nossos acervos, nosso patrimônio.

Entretanto, a questão da Educação Patrimonial é citada apenas para as áreas de Bens Culturais, porém, é muito importante ressaltar que tudo o que tem algum tipo de importância para determinada comunidade pode ser considerado um bem cultural, portanto, a educação patrimonial deveria ser implantada em todo o território nacional.

Programa: Brasil: Destino turístico Internacional Objetivo: Aumentar o fluxo de turistas estrangeiros no País

Público-alvo: Turistas estrangeiros e trade turístico Projetos:

Fórum Mundial de Turismo, Paz e Desenvolvimento;

Salão Brasileiro do Turismo.

Atividades:

Apoio à Comercialização e ao Fortalecimento do Turismo no Brasil; Assistência Médica e Odontológica aos Servidores, Empregados e seus Dependentes;

Assistência Pré-Escolar aos Dependentes dos Servidores e Empregados;

Auxílio-Alimentação aos Servidores e Empregados;

Auxílio-Transporte aos Servidores e Empregados; 
Campanha para a Promoção do Brasil como Destino Turístico Internacional;

Capacitação de Servidores Públicos Federais em Processo de Qualificação e Requalificação;

Captação, Promoção e Participação em Eventos Internacionais;

Concessão de Prêmio para Monografias e Reportagens sobre Negócios e Oportunidades do Turismo;

Funcionamento de Escritórios de Fomento ao Turismo no Exterior; Gestão e Administração do Programa;

Publicidade de Utilidade Pública.

(PPA 2004-2007: 2003, vol. II, p. 88).

Esse programa visa a promoção do Brasil no mercado turístico internacional, mostrando através de eventos, congressos, feiras e até mesmo os escritórios de fomento no exterior, as potencialidades do Brasil no que diz respeito a atividade turística.

Contudo, a forma como está sendo contemplado esse programa, deixa bastante claro a intenção de aumento de fluxo de turistas estrangeiros, portanto aumento da circulação de dinheiro, caracterizando-o como um turismo de massa, gerador de lucro, sem preocupação com a sustentabilidade dos destinos Brasileiros, suas capacidades de carga e a conservação do patrimônio, seja natural ou cultural.

Programa: Cultura e Tradições: Memória Viva Objetivo: Identificar, promover e preservar bens culturais de natureza imaterial

Público-alvo: Sociedade

Atividades:

Fomento a Projetos na Área do Patrimônio Cultural Imaterial;

Gestão e Administração do Programa;

Identificação e Inventário para o Referenciamento de Bens do Patrimônio Cultural de Natureza Imaterial;

Promoção e Intercâmbio de Eventos Voltados para a Preservação de Bens Culturais de Natureza Imaterial;

Registro de Bens Culturais de Natureza Imaterial.

(PPA 2004-2007: 2003, vol. II, p. 148). 
Um programa bastante importante tanto para a conservação da cultura popular brasileira como também para a sustentabilidade da atividade turística. Uma vez que este tem por objetivo identificar, promover e preservar os bens culturais de natureza imaterial de nosso país, bens estes que retratam a peculiaridade da cultura de nosso povo.

Entretanto, mesmo sendo as atividades propostas pelo programa importantes para a preservação de nossa cultura, essas não conseguiram contemplar de forma macro seus objetivos, pois para que se possa preservar é necessário conhecer, vivenciar, e isso acontece através de programas que contemplem a educação patrimonial, fazendo com que a consciência cidadã seja despertada desde a infância, criando um comprometimento entre o cidadão e sua cultura.

Programa: Cultura,Identidade e Cidadania

Objetivo: Produzir,difundir e dar acesso às populações carentes aos bens e serviços culturais valorizando a criatividade popular, oferecendo condições de expressão desenvolvimento de talentos e métodos modernos de comunicação

Público-alvo: Populações residentes em cidades de pequeno e médio porte áreas de periferia de grandes cidades

Projetos:

Instalação e Modernização de Espaços Culturais em Áreas habitadas por populações em Situação de Vulnerabilidade Social.

\section{Atividades:}

Capacitação de Artistas,Técnicos e Produtores em Arte e Cultura em Áreas habitadas por Populações em Situação de Vulnerabilidade Social;

Fomento a Projetos de Produção e Difusão Cultural em Áreas habitadas por Populações em situação de Vulnerabilidade Social;

Gestão e Administração do Programa;

Promoção e Intercâmbio de Eventos Culturais em Áreas habitadas por Comunidades em Situação de Vulnerabilidade Social.

(PPA 2004-2007: 2003, vol. II, p. 150).

Esse programa, aparentemente de cunho social, representa muito para a cultura brasileira, pois tem como objetivo aproximar as pessoas de sua cultura, criar 
possibilidades para que todos tenham oportunidade de vivenciar sua história, sua memória e construir sua identidade cultural.

Dessa forma, esse programa também contribui com a atividade turística, mesmo que de forma indireta, quando incentiva as populações a conhecer a cultura, podendo assim se tornar agente multiplicador de cultura, socializando o conhecimento e assim diminuindo através da cultura a vulnerabilidade social.

Programa Educação Ambiental para Sociedades Sustentáveis Objetivo: Estimular e apoiar processos de educação ambiental, na construção de valores e relações sociais, conhecimentos, habilidades, atitudes e competências que contribuam para a participação de todos na edificação de sociedades sustentáveis

Público-alvo: Educadores ambientais, profissionais de ensino, estudantes, gestores, técnicos, profissionais da mídia e voluntários atuantes na área ambiental e usuários e manejadores diretos de recursos ambientais

\section{Projetos:}

Implantação do Sistema Brasileiro de Informação sobre Educação Ambiental.

\section{Atividades:}

Capacitação de Recursos Humanos para a Prevenção e Controle Ambiental nas Áreas Marítimas e Portuárias;

Educação Ambiental para Recursos Hídricos;

Educação para Conservação da Biodiversidade;

Fomento a Projetos Integrados de Educação Ambiental;

Formação de Educadores Ambientais; Gestão e Administração do Programa.

(PPA 2004-2007: 2003, vol. II, p. 240).

Esse programa representa uma importante alternativa para incentivar a consciência da população em relação ao ambiente, sobre a utilização dos recursos naturais, o que também representa importância fundamental para o turismo, que se utiliza do ambiente para sua existência. 
Entretanto, é importante ressaltar que não apenas o patrimônio natural deveria ser contemplado nessa prática, mas também o patrimônio cultural, fazendo então a educação patrimonial, que abrange a questão ambiental e cultural.

Programa: Monumenta

Objetivo: Revitalizar o Patrimônio cultural em centros urbanos, criando condições para a sua sustentabilidade

Público-alvo: Município com potencial cultural a ser explorado

Projetos:

Capacitação de Técnicos na Área do Patrimônio Histórico;

Educação Patrimonial na Área do Monumenta;

Preservação do Patrimônio Histórico Urbano.

Atividades:

Gestão e Administração do Programa.

(PPA 2004-2007: 2003, vol. II, p. 401).

O Programa Monumenta representa uma conquista bastante importante para o patrimônio cultural brasileiro, pois além da revitalização do patrimônio cultural, o programa procura formas para que esse patrimônio revitalizado possa se manter conservado com o passar dos anos, além de incentivar a prática da educação patrimonial que representa um papel fundamental no que diz respeito a consciência de preservar os bens patrimoniais brasileiros.

Programa: Turismo no Brasil: Uma viagem para todos Objetivo: Aumentar o fluxo do Turismo mediante a estruturação e diversificação da oferta turística brasileira

Público-alvo: Turistas domésticos e trade turístico Projetos:

Adequação da Infra-estrutura do Patrimônio Histórico e Cultural para a Utilização Turística;

Implantação de Centros de Informações Turísticas;

Atividades:

Assistência Médica e Odontológica aos Servidores, Empregados e seus Dependentes;

Assistência Pré-Escolar aos Dependentes dos Servidores e Empregados;

Auxílio- Alimentação aos Servidores e Empregados;

Auxílio- Transporte aos Servidores e Empregados; 
Campanha para Promoção do Turismo no Mercado Nacional; Capacitação de Gestores Públicos e Empreendedores na Área do Turismo;

Capacitação de Servidores Públicos Federais em Processo de Qualificação e Requalificação;

Certificação de Empreendimentos, Equipamentos e Produtos do segmento Turístico;

Certificação de Profissionais associados ao Segmento de TURISMO; Classificação das Empresas, Empreendimentos e Equipamentos Turísticos;

Concessão de Prêmio de Qualidade para o Turismo e Hospitalidade;

Disseminação de Cultura Receptiva ao Turismo;

Estruturação de Roteiros Turísticos Priorizados;

Fiscalização dos serviços Turísticos;

Fomento a Criação de Associações de Turismo Segmentado;

Fomento à produção Local e Distribuição de Produtos para uso dos Empreendimentos Turísticos;

Gestão e Administração do Programa;

Inventário da Oferta Turística;

Oficinas de Sensibilizaçãoe e de Adequação dos Produtos para o Turismo.

\section{Operações Especiais:}

Apoio a Projetos de Infra-estrutura Turística;

Financiamento da Infra-estrutura Turística Nacional;

Participação da União em Projetos de Infra-estrutura no âmbito do Prodetur JK.

(PPA 2004-2007: 2003, vol. II, p. 571).

Este programa representa muito para o País e não apenas para o turismo doméstico brasileiro, mas também para o turismo internacional e principalmente para a população brasileira, pois com a intenção de aumentar o fluxo doméstico em nosso país o programa aponta a necessidade de melhoria de infra-estrutura, capacitação de mão-de-obra, certificação dos estabelecimentos e profissionalização da atividade turística.

O programa prevê ainda a adequação do Patrimônio Histórico e Cultural para a utilização do turismo, contudo, esse ponto merece atenção especial, pois não estamos falando apenas de um patrimônio físico e sim a materialização da cultura de uma comunidade, não que esse patrimônio não possa ser utilizado como atrativo 
turístico, pode sim, contudo, através de ações organizadas, com comprometimento e responsabilidade com a conservação desses bens, sem deixar que o fluxo, entendido como turismo de massa, degrade a cultura da localidade.

De acordo com o PPA 2004-2007 é visível a interpretação que o poder público tem da atividade turística, uma visão de atividade econômica, simplesmente geradora de emprego e renda, com excessão do Ecoturismo que é vinculado aos recursos naturais e culturais. A preocupação principal do governo com respeito ao turismo se dá principalmente em relação a programas capazes de alavancar o fluxo de turistas no país, principalmente de turistas estrangeiros, através de campanhas para a promoção do Brasil como destino internacional, além da participação do País em eventos internacionais.

Evidencia-se que o turismo incentivado pelos programas de governo é o turismo de massa, pois é a modalidade de turismo capaz de gerar lucro, emprego e renda em um curto espaço de tempo, contudo, o turismo de massa não se preocupa com as conseqüências dessa exploração em médio e longo prazo, principalmente no que re refere a conservação do patrimônio brasileiro.

Em contrapartida e de uma forma bastante contraditória o PPA 2004-2007 aborda com muita propriedade a questão da conservação do patrimônio cultural, sendo até mesmo bastante detalhista nos programas que tratam desse assunto. Contudo, o desvinculamento do patrimônio cultural em relação a atividade turística é preocupante, pois se o turismo se utiliza do patrimônio brasileiro como atrativo, como é possível ter programas e projetos distintos para essas áreas? Esses programas deveriam estar contemplados de forma a atingir um objetivo único, onde 
patrimônio e turismo aparecem unidos para a sustentabilidade tanto da atividade turística quanto da conservação do patrimônio nacional.

\subsection{O Plano Nacional de Turismo - PNT}

O Plano Nacional de Turismo - PNT se caracteriza por sua especificidade, mostra de forma bastante clara a vocação do País para a implementação da atividade turística, contudo, ainda trata o turismo muitas vezes como fonte permanente de riqueza, lucro, referindo-se à potencialidade econômica.

De acordo com o PNT (2003, p. 08) o turismo:

- deverá se transformar em fonte geradora de novos empregos e ocupações, proporcionando uma melhor distribuição de renda e melhorando a qualidade de vida das comunidades;

- ao contribuir para multiplicar os postos de trabalho no território nacional, poderá interferir positivamente no âmbito da violência urbana, fortalecendo a segurança da população;

- deverá transformar-se em um agente da valorização e conservação do patrimônio ambiental (cultural e natural), fortalecendo o princípio da sustentabilidade;

- tornar-se-á um instrumento de organização e valorização da sociedade, articulando seus interesses econômicos, técnicos, científicos e sociais, com o lazer, a realização de eventos, feiras e outras atividades afins;

- poderá, por meio de programas de qualificação profissional, elevar a qualidade da oferta turística nacional, fator essencial para inserir o país competitivamente no mercado internacional;

- atuará como mecanismo instigador de processos criativos, resultando na geração de novos produtos turísticos apoiados na regionalidade, genuinidade e identidade cultural do povo brasileiro, fortalecendo a autoestima nacional e a de nossas comunidades;

- a partir das novas políticas sociais, poderá configurar-se como uma das mais eficazes expressões do uso do tempo liberado do trabalhador, contribuindo para a sua saúde física e mental; 
- ao ser fortalecido internamente pelo exercício contínuo e sistêmico de consumo pela sociedade brasileira, deverá criar as condições desejáveis para a estruturação de uma oferta turística qualificada capaz de atender melhor o mercado internacional;

- para alcançar as metas desejáveis no balanço de pagamentos, exigirá normatização e legislação adequadas com vistas à facilitação e o aumento da entrada de turistas estrangeiros;

- por sua dinâmica, necessita de uma constante troca de informações entre os destinos turísticos, a oferta, e os mercados consumidores, o que requer investimentos constantes em marketing.

O PNT mostra claramente a intenção governamental de investir no setor do turismo, através de parcerias capazes de fomentar a atividade e conseqüentemente transformá-la em fonte geradora de novos empregos e ocupações, proporcionando uma melhor distribuição de renda e melhorando assim a qualidade de vida das comunidades, diminuindo os índices de violência urbana, fortalecendo a segurança da população.

Mostra de forma bastante clara que o turismo, se bem planejado, seguindo modelos adequados, responsáveis, justos, onde as comunidades tenham a oportunidade de participar do processo, pode vir a ser um importante facilitador no que diz respeito a inclusão dos mais variados agentes sociais.

Menciona ainda que os recursos gerados pelos turistas circulam a partir dos gastos praticados em hotéis, bares, restaurantes, áreas de diversão e entretenimento, o que significa que todo o comércio local é beneficiado.

Tem por objetivos principais a diversificação da oferta turística brasileira, a melhoria e estruturação dos destinos turísticos nacionais, a qualificação do produto turístico do país, a ampliação e a qualificação do mercado de trabalho, o aumento da 
taxa de permanência e o gasto médio do turista no país, além de fazer com que o Destino Brasil se torne mais competitivo no mercado internacional.

Assim, o turismo deverá transformar-se em agente de valorização e conservação do patrimônio, seja cultural ou natural, fortalecendo o princípio da sustentabilidade, além de ser um instrumento de valorização da sociedade, articulando seus múltiplos interesses.

O PNT incentiva programas de qualificação profissional com o intuito de elevar a qualidade da oferta turística e tornar o país mais competitivo internacionalmente, além de instigar processos criativos com a intenção de fomentar novos produtos turísticos pautados na regionalidade, genuinidade, identidade cultural brasileira, fortalecendo a auto-estima nacional e de nossas comunidades.

O PNT contempla de forma bastante responsável o patrimônio, fazendo do turismo um agente de preservação e conservação dos bens culturais nacionaos, bens que fazem parte não apenas da atividade turística mas da história do país.

Contudo, existe uma grande contradição nesse discurso, pois fica bastante evidente a intenção do governo em desenvolver a atividade turística, por se tratar de uma atividade capaz de gerar emprego e renda, entretanto, o turismo que está sendo incentivado pelo poder público é justamente o turismo de massa, gerador de lucro imediato, sem muito comprometimento com a conservação nem da própria atividade, muito menos do patrimônio que o turismo utiliza como atrativo, sendo assim impossível colocar em prática os princípios do desenvolvimento sustentável, haja vista que a questão da conservação do patrimônio e da natureza só representam importância no discurso, pois na prática nem sequer existem. 


\subsection{O Instituto do Patrimônio Histórico e Artístico Nacional - IPHAN}

O Instituto do Patrimônio Histórico e Artístico Nacional - IPHAN, órgão vinculado ao Ministério da Cultura, é o responsável a mais de 70 anos pela conservação, proteção e salvaguarda do Patrimônio Cultural Brasileiro, e tem exercido essa tarefa com muita responsabilidade e profissionalismo.

De acordo com informações registradas em seu endereço eletrônico, a tarefa reservada ao IPHAN é preservar, conservar e salvaguardar a riqueza distribuída em toda dimensão continental brasileira, a diversidade dos elementos formadores de sua sociedade, a riqueza e variedade de seus ecossistemas, enfim, todo o universo cultural brasileiro.

O IPHAN tem como missão identificar, proteger, restaurar, preservar, documentar, divulgar e finalmente fiscalizar os bens culturais do nosso país, com a intenção de assegurar a perpetuação e o usufruto desses bens não apenas para a atual geração mas também para as gerações futuras.

Contudo, mesmo com as ações do IPHAN, do Ministério da Cultura e do Turismo, das ações e programas previstos no Plano Plurianual, ainda assim não se tem a atenção necessária para a questão da preservação do nosso patrimônio, o governo ainda não trata essa questão como sendo de importância fundamental assim como educação, e é justamente inserido na educação que o patrimônio tem que estar, criando uma consciência responsável, cidadã, não apenas do governo, mas da população em geral. 


\section{CONSIDERAÇÕES FINAIS}

Este trabalho procurou mostrar a importância da preservação do patrimônio, seja ele natural ou cultural, para a atividade turística, ressaltando a necessidade da preservação como vetor de importância fundamental para a manutenção da identidade cultural de um povo, sua história, seus costumes, sua cultura.

A educação patrimonial foi apresentada como uma aliada importante no processo de desenvolvimento do turismo, por tornar esse processo mais responsável e comprometido, assegurando a sensibilização de todos em relação à importância do patrimônio e gerando uma consciência cidadã nas comunidades.

Foram apresentados alguns conceitos acerca do turismo, do desenvolvimento sustentável, além de sua importância no contexto em que vivemos, com a finalidade de elaborar o embasamento teórico necessário para então discutir o patrimônio, a educação patrimonial e conseqüentemente a interação entre patrimônio e sustentabilidade, além da visão governamental dessa interação.

O trabalho mostrou como o turismo, o desenvolvimento sustentável e o patrimônio estão sendo interpretados pelo poder público e pela academia, evidenciando o fato de ainda estarmos tratando questões de suma importância sem a devida relevância, mostrou ainda que as ações governamentais ainda não estão concatenadas com os pensamentos dos que estudam a atividade turística e o patrimônio.

Evidenciou também a falta de consciência da população em relação a seu patrimônio, e principalmente o desconhecimento da importância da prática do 
turismo com base nos princípios da sustentabilidade para a preservação desse patrimônio.

Além disso, o trabalho mostrou que a educação patrimonial é uma ferramenta importantíssima no que diz respeito ao conhecimento do patrimônio nacional, e por esse motivo deveria estar sendo difundida em nosso País das mais diversas maneiras, como disciplina escolar, de acordo com os Parâmetros Curriculares Nacionais, em forma de projetos para as comunidades e até mesmo através de campanhas de proteção do patrimônio.

Entretanto, ficou bastante evidente a contradição do poder público quando interpreta o turismo como uma atividade meramente comercial, de massa, caracterizada pela geração de lucro a curto prazo sem comprometimento com questões de preservação do patrimônio nacional e ao mesmo tempo propõe ações de preservação do patrimônio cultural brasileiro. Contudo, é importante ressaltar que o turismo de massa não está configurado dentro das perspectivas da sustentabilidade, portanto, essa modalidade de turismo não é capaz de preservar o patrimônio cultural brasileiro.

Portanto, para que possamos desenvolver de forma sustentável o turismo, além de utilizar o artifício da educação patrimonial como base sólida para a preservação do patrimônio nacional, é necessário também que o poder público passe a entender o patrimônio e o turismo sustentável como vigas de sustentação da história e cultura de nosso povo, destinando a eles a atenção e importância necessária para tornar a conservação do patrimônio uma verdade e uma vontade nacional. 


\section{REFERÊNCIAS}

ALMEIDA, J. A.; FROEHLICH, J. M.; RIEDI, M. (org.) Turismo Rural e Desenvolvimento Sustentável. Campinas, SP: Papirus, 2000.

ANDRADE, J. V. Turismo: fundamentos e dimensões. São Paulo: Ática, 1997.

ARJONA, M. Patrimonio Cultural e Identidad. La Habana, Cuba: Editorial Letras Cubanas, 1986.

ASSUNÇÃO, P. Patrimônio. São Paulo: Loyola, 2003.

BARRETO, M. Turismo e Legado Cultural. Campinas: Papirus, 2000.

Turismo e Patrimônio: meios ou fins? I Jornada de Turismo, Meio Ambiente e Patrimônio Cultural. São Paulo: UNIBERO, 2001.

BRENER, J. Jornal do século XX. São Paulo: Moderna, 1998.

CARDÔZO, L. S.; AlBARELlO, T. H.; DIAS, G.; SOARES, A. L. R. A inserção da Educação Patrimonial no Centro Histórico Coronel Pillar. Revista Educação Patrimonial. Ano 1, no 1, outubro de 2006.

CHOAY, F. A alegoria do Patrimônio. São Paulo: UNESP, 2001.

CORIOLANO, L. N. M. T. (org.) Turismo com Ética. Fortaleza, CE: UECE, 1998.

Local. Fortaleza, CE: FUNECE, 2003.

O Turismo de Inclusão e o Desenvolvimento

DENCKER, A. de F. M. Métodos e Técnicas de Pesquisa em Turismo. $7^{\text {a }}$ ed. São Paulo: Futura, 2005.

DIAS, R. Turismo Sustentável e Meio Ambiente. São Paulo: Aleph, 2000.

. Turismo Sustentável e Meio Ambiente. São Paulo: Atlas, 2003.

ECO. U. Como se faz uma tese. São Paulo: Perspectiva, 1996.

FERREIRA, A. B. H. Minidicionário da Língua Portuguesa. Rio de Janeiro: Editora Nova Fronteira, 1989.

FITZSIMMONS, J. A; FITZSIMMONS, M. J. Administração de serviços: estratégia e tecnologia de informação. Porto Alegre: Bookman, 2000.

FREIRE, P. Pedagogia da Autonomia. São Paulo: Paz e Terra, 1996. 
FUNDAÇÃO JOÃO PINHEIRO, Centro de Estudos Históricos e Culturais. Pesquisa Educação Patrimonial: sibsídios para elaboração de proposta de ação educativa. Caderno do CEHC. Série Cultura № 2. Belo Horizonte: 2001.

FUSTER, F. L. Teoria y Técnica del Turismo. Madri: Nacional, 1947.

HAIGERT, C. G. Estado da Arte sobre a Educação Patrimonial. In: SOARES, A. L. R. (org.) Educação Patrimonial: relatos e experiências. Santa Maria, RS: UFSM, 2003.

HORTA, M. L. P. Educação Patrimonial. Programa sobre Educação Patrimonial da Série Salto para o Futuro/ TV ESCOLA. TVE BRASIL, 2003.

HORTA, M. L. P.; GRINBERG, E.; MONTEIRO, A. Q. Guia Básico de Educação Patrimonial. Brasília: Instituto do Patrimônio Histórico e Artístico Nacional, Museu Imperial, 1999.

IGNARRA, L. R. Fundamentos do Turismo. São Paulo: Pioneira Thomson Learning, 2003.

IRVING, M. A.; AZEVEDO, J. Turismo: o desafio da sustentabilidade. São Paulo: Futura, 2002.

KOTLER, P.; ARMSTRONG, G. Princípios de Marketing. Rio de Janeiro: Editora LTC, 1999.

LEMOS, C. O que é Patrimônio Histórico. $5^{\mathrm{a}}$ ed. São Paulo: Brasiliense, 1987.

MACHADO, L. A.; ATAÍDES, H. S. F. Identidade Cultural e Memória - objetivos de construção do patrimônio histórico. Revista de Divulgação Científica. Goiânia, 1998.

MAGALHÃES, S. M. F. Educação Patrimonial através da compreensão da Arquitetura de Museus da Cidade de São Paulo: São Paulo, 2006.

São Paulo, 2005.

. Educação Patrimonial: uma proposta para a cidadania.

MARQUES, F. Guia prático da qualidade total em serviços. São Paulo: APMS, 1997.

MARTINS, J. C. O. (org.) Turismo, Cultura e Identidade. São Paulo: Roca, 2003.

MARTINS, A. B.; VIEIRA, G. F.; ALCÂNTARA, A. A.; BRAZ, C. L.; BRIDI, D.; CARNEIRO, E. K. Turismo e Patrimônio Cultural: possíveis elos entre identidade, memória e preservação. s/d.

OLIVEIRA, A. P. Turismo e desenvolvimento: planejamento e organização. São Paulo: Atlas, 2002.

OMT. Introdução ao Turismo. São Paulo: Roca, 2001. 
$\overline{2003 .}$

Turismo Internacional: uma perspectiva global. Porto Alegre: Bookman,

Guia de Desenvolvimento do Turismo Sustentável. Porto Alegre: Bookman, 2003.

PAOLI, M. C. Memória, História e Cidadania. In: O Direito à Memória: o patrimônio histórico e cidadania. São Paulo: Secretaria Municipal de Cultura, 1992.

PETROCCHI, M. Turismo: planejamento e gestão. São Paulo: Futura, 1998.

PIRES, M. J. Gestão de Cidades Históricas para o Turismo: questões teóricas e práticas. Turismo em Análise, São Paulo, 2003.

PLANO NACIONAL DE TURISMO. Diretrizes Metas e Programas. Brasília, 2003.

PLANO PLURIANUAL FEDERAL 2004-2007. Volume I, Brasília, 2003.

. Volume II, Brasília, 2003.

Lazer e Turismo Cultural. São Paulo: Manole, 2002.

PORTUGUEZ, A. P. Agroturismo e desenvolvimento regional. São Paulo: Hucitec, 2002.

Roca, 2004. (org.) Turismo, Memória e Patrimônio Cultural. São Paulo:

POSSATI, J. A. Turismo e Educação Patrimonial. s/d.

QUEIROZ, M. N. A Educação Patrimonial como Instrumento de Cidadania. Revista Museu, outubro de 2006.

RABAHY, W. A. Turismo e Desenvolvimento: estudos econômicos e estatísticos no planejamento. Barueri, SP: Manole, 2003.

ROSS, G. F. Psicologia do Turismo. São Paulo: Contexto, 2001.

RUSCHMANN, D. V. de M. Marketing turístico: um enfoque promocional. Campinas, SP: Papirus, 1990.

SEGALA, L. Identidade, Educação e Patrimônio: o trabalho do Laboep. Revista do IPHAN, vol. 03, Dossiê Educação Patrimonial, Rio de Janeiro: IPHAN, 2005.

SHIOZAWA, R. S. C. Qualidade no Atendimento e Tecnologia de Informação. São Paulo: Atlas, 1993.

SWARBROOKE, J. Turismo Sustentável: gestão e marketing. São Paulo: Aleph, 2000. 
Paulo: Aleph, 2000.

. Turismo Sustentável: turismo cultural, ecoturismo e ética. São

TEIXEIRA, J. G. L. C.; GARCIA, M. V. C.; GUSMÃO, R. Patrimônio Imaterial, Performance Cultural e (re)tradicionalização. Brasília: ICS-UnB, 2004.

TRIGUEIRO, C. M. Marketing \& Turismo: como planejar e administrar o marketing turístico para uma localidade. Rio de Janeiro: Qualitymark Ed., 2001.

WAHAB, S. E. Introdução à Administração do Turismo. São Paulo: Pioneira, 1977.

VELOSO, M. P. Turismo Simples e Eficiente: um guia com orientações básicas para municípios. São Paulo: Roca, 2003.

WAINBERG, J. A. Turismo e comunicação: a indústria da diferença. São Paulo: Contexto, 2003.

Sítios consultados

www.cultura.gov.br

www.educacional.com.br

www.educacaopatrimonial.com.br

www.iepha.mg.gov.br

www.iphan.gov.br

www.labjor.unicamp.br

www.memoriaviva.org.br

www.museuimperial.gov.br

www.mma.gov.br

www.mtur.gov.br

www.planalto.gov.br

www.revistamuseu.com.br

www.tvebrasil.com.br 